\title{
CALCÁRIOS E ROCHAS FOSFÁTICAS DO GRUPO CORUMBÁ NA SERRA DA BODOQUENA, MS: MODELO GENÉTICO
}

P.C.Boggiani ${ }^{1}$

A.M.Coimbra ${ }^{2}$

T.R.Fairchild ${ }^{2}$

Ocorrências de rochas fosfáticas no Grupo Corumbá foram inicialmente descobertas pela DOCEGEO na região de Bonito em 1976. A descoberta de novas ocorrências permitiu a elaboração de modelo genético onde as rochas fosfáticas tiveram origem a partir de correntes ascencionais marinhas (upwellings).

O Grupo Corumbá é caracterizado por sedimentos predominantemente carbonáticos, de provável idade proterozóica superior (vendiana) ou, possivelmente, cambriana, expostos ao longo de faixa alongada e descontínua, com aproximadamente $600 \mathrm{~km}$ de comprimento, na região centro-oeste dos estados de Mato Grosso e Mato Grosso do Sul, incluindo as exposições da Serra da Bodoquena (MS), Corumbá (MS) e Serra das Araras (MT). Esta unidade estratigráfica inserese na Faixa Paraguai, que bordeja a margem sul do Cráton Amazônico. Na Serra da Bodoquena, foi subdividida em duas zonas paralelas, denominadas Interna e Externa. Os depósitos fosfáticos encontram-se na Zona Interna (porção leste da faixa), mais deformada que a Zona Externa.

Na Zona Externa (parte oeste da faixa), com deposição de fanglomerados seguida por transgressão marinha com sedimentação carbonática em sabkha litorânea, ocorrem três fácies terrígenas (conglomerados, arcósios e lamitos), associadas a cinco fácies carbonáticas ( grainstones com laminações cruzadas e pseudomorfos de gipsita, margas e mudstones alternados, mudstones pseudonodulares, mudstones, e calcários estromatoliticos silicificados).

${ }^{1}$ CCET, UFMS.

${ }^{2}$ Departamento de Paleontologia e Estratigrafia, Instituto de Geociências, USP. 
$\mathrm{Na}$ Zona Interna as fácies de grainstones ooliticos e brechas intraformacionais com clastos centimétricos discóides (ambientes de águas rasas) contrastam com as fácies de lamitos, mudstones calcfticos e brechas intraformacionais (ambientes de águas profundas), evidenciando deposição carbonática em plataforma e talude, respectivamente .

Os depósitos de rochas fosfáticas (rodovia Bonito-Bodoquena) ocorrem como microfosforito estratificado ou, mais raramente, com estrutura estromatolitica, ou ainda na forma de clastos com frequência de 10 a $20 \%$ e tamanhos e formas variadas em matriz dolomftica ou siliciclástica (sntico-argilosa), à semelhança do observado na Pedreira Laginha, próximo à Corumbá. No município de Bodoquena, são observadas camadas de microfosforito com 1 a $2 \mathrm{~cm}$ de espessura alternadas com camadas de 5 a $8 \mathrm{~cm}$ de quartzo arenito com cimento fosfático. Difratometria de raios $X$ dos microfosforitos permitiu a identificaçâo do mineral fluorapatita, com teores de até $40 \%$ de $\mathrm{P}_{2} \mathrm{O}_{5}$.

$\mathrm{Na}$ Zona Interna, o contraste entre águas rasas e profundas propiciou o surgimento de upwellings permitindo suprimento para os depósitos fosfáticos formados em águas rasas e, posteriormente, em parte retrabalhados e depositados na plataforma e talude.

Com base nas novas ocorrências de rochas fosfáticas e no modelo genético proposto, surgem novas perspectivas para continuidade das pesquisas nas exposições do Grupo Corumbá, não só na Serra da Bodoquena como também na região de Corumbá. 